\title{
Growth-Promoting Actions of Parathyroid Hormone, Adrenocorticotrophic Hormone, and Thyroid-Stimulating Hormone: In Vitro Studies in Normal and Pygmy T-Lymphoblast Cell Lines
}

\author{
MITCHELL E. GEFFNER, NOELLE BERSCH, ALAN B. CORTEZ, ROBERT C. BAILEY, AND \\ DAVID W. GOLDE \\ Departments of Pediatrics [M.E.G., N.B., A.B.C.] and Anthropology [R.C.B.], University of California at \\ Los Angeles, Los Angeles, California 90024, and Memorial Sloan-Kettering Cancer Center, New York, \\ New York 10021 [D.W.G.]
}

\begin{abstract}
We used an in vitro T-lymphoblast clonal proliferation assay ACTH (hACTH)-, and human TSH (hTSH)-stimulated growth of human T-cell leukemia virus-II-transformed T-lymphoblast cell lines from normal individuals and to elucidate the role of IGF-I as the mediator of hPTH-, hACTH-, and hTSH-induced T-cell growth. Normal T-lymphoblast cell lines respond to hIGF-I in a bimodal fashion. The mean first peak response was $143 \pm 9.8 \%$ above baseline (defined as $100 \%$ ) occurring at $8 \mu \mathrm{g} / \mathrm{L}$, and the mean second peak response was $154 \pm 14.4 \%$ occurring at 100 $\mu \mathrm{g} / \mathrm{L}$. Both responses were completely blocked after incubation with $\alpha$ IR-3, an MAb to the IGF-I receptor (by analysis of variance, $p=0.015$ between full response curves). After stimulation with hPTH, the mean peak clonal response of normal T-lymphoblast cell lines was $189 \pm 7.0 \%$; after incubation with $\alpha \mathrm{IR}-3$, the mean peak clonal response was $108 \pm 7.9 \%(p=$ 0.0015 between full response curves). The mean peak clonal response of normal T-lymphoblast cell lines after hACTH stimulation was $192 \pm 8.6 \%$; preincubation with $\alpha \mathrm{IR}-3$ reduced the mean peak clonal response to $94 \pm 1.2 \%(p<0.0001$ between full response curves). With hTSH stimulation, the mean peak clonal response of normal T-lymphoblast cell lines was $167 \pm$ $7.0 \%$; after incubation with $\alpha \mathrm{IR}-3$, the mean peak clonal response was $94 \pm 8.2 \%(p=0.003$ between full response
\end{abstract}

The major actions of PTH, ACTH, and TSH affect calcium and phosphate metabolism, cortisol production, and thyroid hormone synthesis, respectively. These hormones also exert trophic growth-promoting actions on bone, adrenocortical, and thyroid target tissues. In each case, available evidence suggests

Received March 7, 1994; accepted November 13, 1994.

Correspondence and reprint requests: Mitchell E. Gefiner, M.D., UCLA Medical Center, Department of Pediatrics, Los Angeles, CA 90024.

Supported by USPHS Grant CA30388, The National Geographic Society, The Swan Fund, The International Studies and Overseas Programs, UCLA, and the Genentech Foundation for Growth and Development. curves). After stimulation with hIGF-l, hPTH, hACTH, and hTSH, the mean peak clonal responses of a pygmy Tlymphoblast cell line were $112 \pm 8.2,122 \pm 1.5,99 \pm 4.2$, and $98 \pm 5.5 \%$, respectively (all $p \leq 0.0004$ between corresponding complete pygmy and normal response curves). These data indicate that hPTH, hACTH, and hTSH stimulate growth of normal human T-lymphoblast cell lines through local action of IGF-I, because these effects can all be blocked by preincubation with MAb against the IGF-I receptor. The pygmy T-lymphoblast cell line showed little or no clonal expansion in the presence of hIGF-I itself, or in response to hPTH, hACTH, or hTSH, further supporting the notion that an intact IGF-I response mechanism is necessary for the proliferative response to $\mathrm{hPTH}, \mathrm{hACTH}$, and hTSH in human T-lymphoblasts. (Pediatr Res 37: 507-511, 1995)
Abbreviations
hIGF-I, human insulin-like growth factor-I hPTH, human parathyroid hormone
hACTH, human adrenocorticotrophic hormone hTSH, human thyroid-stimulating hormone HTLV, human T-cell leukemia virus IGFBP, IGF binding protein $\mathbf{G H}$, growth hormone

that the growth promotion is mediated by IGF acting either alone or synergistically with the specific trophic hormone (1). To clarify the role of IGF-I as the mediator of PTH-, ACTH-, and TSH-stimulated tissue growth, we first quantified the in vitro clonal proliferation of HTLV-II-transformed Tlymphoblast cell lines established from normal individuals in response to these hormones in the presence and absence of $\alpha \mathrm{IR}-3$, an MAb directed against the IGF-I receptor. The validity of HTLV-II-transformed T-lymphoblast cell lines as a model to study the effects of PTH, ACTH, and TSH is supported by the presence of receptors for each of the hormones on 
normal lymphocytes (2-4). We also examined hPTH-, hACTH-, and hTSH-stimulated clonal responsiveness of a T-lymphoblast cell line established from an African Efe pygmy [previously shown to be resistant to the growth-promoting action of both hGH and hIGF-I in this clonal assay (5)], with the hypothesis that there would be lack of response to each hormone if its growth-promoting effect requires the local action of IGF-I. Using this T-lymphoblast cell model, we confirmed that the growth-promoting actions of hPTH, hACTH, and hTSH are mediated by local IGF-I action, and therefore the pygmy T-lymphoblast cell line showed little or no growth responsiveness to these hormones.

\section{METHODS}

Patients. T-lymphoblast cell lines were established from six normal adult individuals living in the United States and from one adult male Efe pygmy from central Africa $(5,6)$. Procurement of blood from the normal subjects was performed after obtaining informed consent, and with the approval of the UCLA Human Subject Protection Committee. Blood from the pygmy was drawn after the nature of the study was explained; verbal consent only could be obtained. At the time of study, the pygmy subject was estimated to be $27 \mathrm{y}$ old, was $143.6 \mathrm{~cm}$ tall, weighed $46.5 \mathrm{~kg}$, had a body mass index of $22.6 \mathrm{~kg} / \mathrm{m}^{2}$, and had a triceps skinfold thickness of $6.5 \mathrm{~mm}$. The results of plasma studies performed on the pygmy were as follows: IGF-I $=206 \mu \mathrm{g} / \mathrm{L}$ (normal $=135-449 \mu \mathrm{g} / \mathrm{L}$ ), IGF-II $=116 \mu \mathrm{g} / \mathrm{L}$ (normal $=288-736 \mu \mathrm{g} / \mathrm{L})$, IGFBP-3 $=1.9 \mathrm{mg} / \mathrm{L}$ (normal $=$ $1.9-4.2 \mathrm{mg} / \mathrm{L}$ ), and $\mathrm{GH}$ binding protein $=38 \%$ relative specific binding (normal $=54-159 \%$ ).

T-lymphoblast transformation. The methodology for HTLV-II transformation of peripheral blood lymphocytes has been previously described (7-9). Low-density mononuclear cells $\left(1 \times 10^{5} / \mathrm{mL}\right)$, isolated by Ficoll-Hypaque densitygradient separation of $10 \mathrm{~mL}$ of blood, were primed overnight with phytohemagglutinin and IL-2 and then cocultivated with an equal number of lethally irradiated (12000 cGy) latepassage Mo cells (HTLV-II) (10) in Iscove's medium supplemented with $20 \%$ fetal bovine serum and IL-2. Virusproducing, immortalized T-lymphoblast cell lines developed in about 4 wk. Cell lines were fed $2 \mathrm{~d}$ before clonogenic studies to ensure that all experiments were conducted with cells in an exponential growth phase.

Studies of IGF-I, PTH, ACTH, and TSH responsiveness. Fifty thousand transformed $\mathrm{T}$ cells/mL $\left(5 \times 10^{3} /\right.$ well $)$ were cultured in methylcellulose in microtiter plates under serumfree conditions [1.5\% BSA (Intergen Biochemicals, Purchase, NY)] containing either hIGF-I[7-250 $\mu \mathrm{g} / \mathrm{L}$ (Upstate Biotechnology, Inc., Lake Placid, NY)], hPTH-(1-34)[1.2-2.4 × $10^{3}$ $\mathrm{pmol} / \mathrm{L}$ (Sigma Chemical Co., St. Louis, MO)], hACTH-(124)[1.7-3.4 $\times 10^{3} \mathrm{pmol} / \mathrm{L}$ (Sigma Chemical Co.)], recombinant hTSH $\left[0.34-3.4 \times 10^{3} \mathrm{pmol} / \mathrm{L}\right.$ (kindly provided by $\mathrm{Dr}$. Bruce Pratt, Genzyme, Inc., Framingham, MA)], or PBS at pH 7.4. No IL-2 was present in the incubation mixtures. After 4-10 d, colonies containing a minimum of eight cells were enumerated using an inverted phase-contrast microscope. Ex- periments were performed in triplicate, with a replicate variability of $<5 \%$.

Receptor antibody studies. Normal T-lymphoblast cell line clonal responses to hIGF-I, hPTH, hACTH, or hTSH were quantified in the presence or absence of $\alpha \mathrm{IR}-3$, an $\mathrm{IgG}_{1} \mathrm{MAb}$ against the IGF-I receptor (11) (Oncogene Science, Inc., Manhasset, NY). To ensure the specificity of any blockade induced by $\alpha \mathrm{IR}-3$, normal T-lymphoblast cell line clonal responses to hIGF-I, hPTH, hACTH, and hTSH were also quantified in the presence or absence of $\mathrm{E} 9$, an $\mathrm{IgG}_{1}$ anti-neutrophil MAb (kindly provided by Dr. Loran Clement, Department of Pediatrics, UCLA). Antibodies were added $1 \mathrm{~h}$ before hormones at a final concentration of $5 \times 10^{-5} \mathrm{~g} / \mathrm{L}$.

Data analysis. The unstimulated number of T-lymphoblast colonies formed in incubation mixtures without added hormone is defined as $100 \%$. Data are presented as the mean ( \pm SEM). Statistical comparisons between basal colony counts were made by $t$ test and between full response curves by repeated measures two-factor analysis of variance.

\section{RESULTS}

Normal T-lymphoblast cell lines: hIGF-I, hPTH, hACTH, and hTSH responsiveness in the presence or absence of $\alpha I R-3$. Mean basal colony counts without added $\alpha \mathrm{IR}-3$ were $82.7 \pm 12.8$ (hIGF-I), $40.1 \pm 6.4(\mathrm{hPTH}), 41.7 \pm 4.7$ (hACTH), and $37.6 \pm 12.4$ (hTSH); in the presence of $\alpha \mathrm{IR}-3$, the corresponding mean mean basal colony counts were $79.3 \pm$ $12.2,58.3 \pm 6.1,66.8 \pm 15.2$, and $34.4 \pm 12.1$ (all $p=\mathrm{NS}$ versus no $\alpha \mathrm{IR}-3$ ), i.e. they were not reduced by $\alpha \mathrm{IR}-3$.

As we have previously reported (5), responsiveness of normal T-lymphoblast cell lines after stimulation with IGF-I was bimodal in nature. The first mean peak clonal response to hIGF-I (mean of three studies using three T-lymphoblast cell lines) was $144 \pm 9.3 \%$ above baseline (defined as 100\%) occurring at $8 \mu \mathrm{g} / \mathrm{L}$, and the mean second peak response was $154 \pm 14.4 \%$ occurring at $100 \mu \mathrm{g} / \mathrm{L}$. After incubation with $\alpha$ IR-3, there was complete obliteration of all IGF-I-induced clonal responsiveness ( $p=0.015$ between full response curves) (Fig. 1).

In response to $\mathrm{hPTH}$, the mean peak clonal response of normal T-lymphoblast cell lines (mean of 18 studies using seven T-lymphoblast cell lines) was $189 \pm 7.0 \%$ occurring at a $\mathrm{hPTH}$ concentration of $18 \mathrm{pmol} / \mathrm{L}$; after incubation with $\alpha$ IR-3, the mean peak clonal response (mean of five studies using five T-lymphoblast cell lines) was significantly blunted to $108 \pm 7.9 \%$ ( $p=0.0015$ between full response curves) (Fig. 2).

After stimulation with hACTH, the mean peak clonal response of normal T-cell lines (mean of seven studies using five T-lymphoblast cell lines) was $192 \pm 8.6 \%$ occurring at a hACTH concentration of $34 \mathrm{pmol} / \mathrm{L}$; after incubation with $\alpha$ IR-3, clonal responsiveness was abolished (mean of four studies using four T-cell lines) with the mean peak response less than baseline $[94 \pm 1.2 \%(p<0.0001$ between full response curves)] (Fig. 3).

The mean peak clonal response of normal T-lymphoblast cell lines after stimulation with hTSH (mean of eight studies 


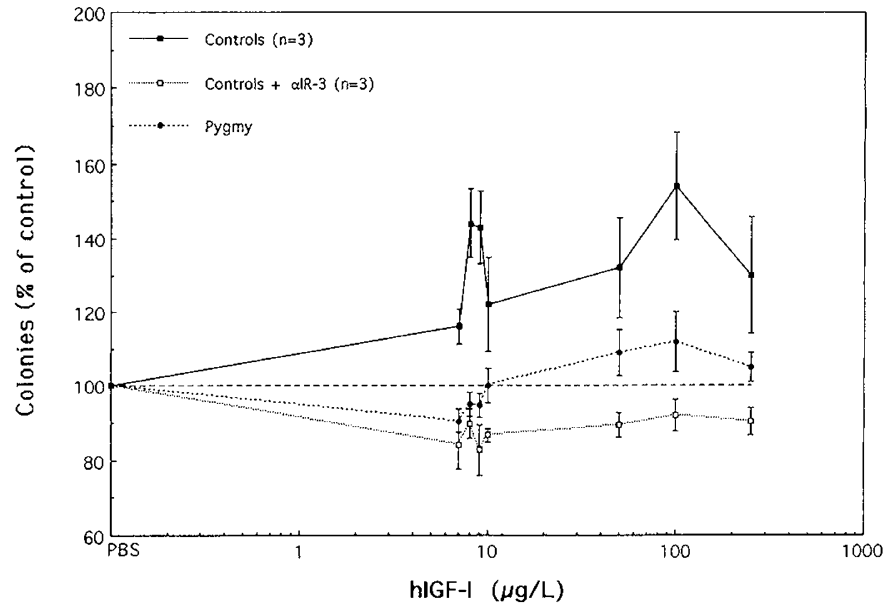

Figure 1. hIGF-I responsiveness. The mean first peak clonal response of normal T-lymphoblast cell lines to hIGF-I was $144 \pm 9.3 \%$, and the mean second peak clonal response was $154 \pm 14.4 \%$. After preincubation with $\alpha$ IR-3 MAb to the IGF-I receptor, responsiveness to hIGF-I was completely blocked. Additionally, the pygmy T-lymphoblast cell line showed minimal responsiveness to hIGF-I. In all figures, the unstimulated number of $\mathrm{T}$ lymphoblast colonies (referred to, on the ordinate, as colonies) formed in incubation mixtures without added hormone is defined as $100 \%$ and the abscissa represents the concentration of added hormone. The data are presented as the mean \pm SEM.

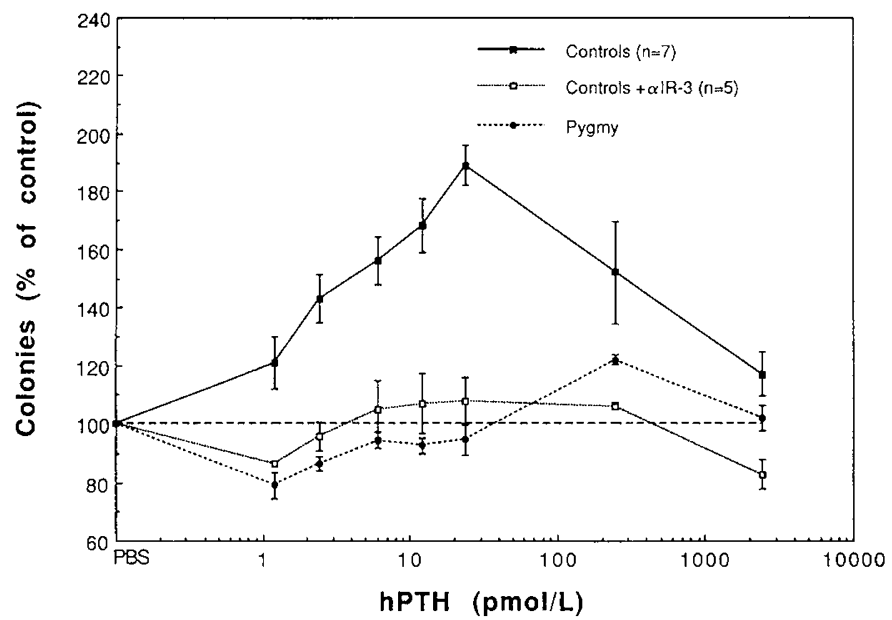

Figure 2. hPTH responsiveness. The mean peak clonal response of normal T-lymphoblast cell lines to hPTH was $189 \pm 7.0 \%$. After preincubation with $\alpha \mathrm{IR}-3$, responsiveness to hPTH was significantly blunted. Additionally, responsiveness of the pygmy T-lymphoblast cell line to hPTH was significantly less than that of normal T-lymphoblast cell lines.

using four T-lymphoblast cell lines) was $167 \pm 7.0 \%$ occurring at a hTSH concentration of $3.4 \mathrm{pmol} / \mathrm{L}$; after incubation with $\alpha \mathrm{IR}-3$, the mean peak clonal response (mean of four studies using four T-lymphoblast cell lines) was less than baseline [94 $\pm 8.2 \%$ ( $p=0.003$ between full response curves)] (Fig. 4).

There were no significant differences in peak clonal responses after hormonal stimulation in the presence or absence of E9 anti-neutrophil MAb [hIGF-I: --E9, 142\% (first peak) and $144 \%$ (second peak), +E9, 148\% (first peak) and $144 \%$ (second peak); hPTH: -E9, 170\%, +E9, 176\%; hACTH: $-\mathrm{E} 9,193 \%$, +E9, 173\%; and hTSH: $-\mathrm{E} 9,174 \%,+\mathrm{E} 9$, $168 \%]$.

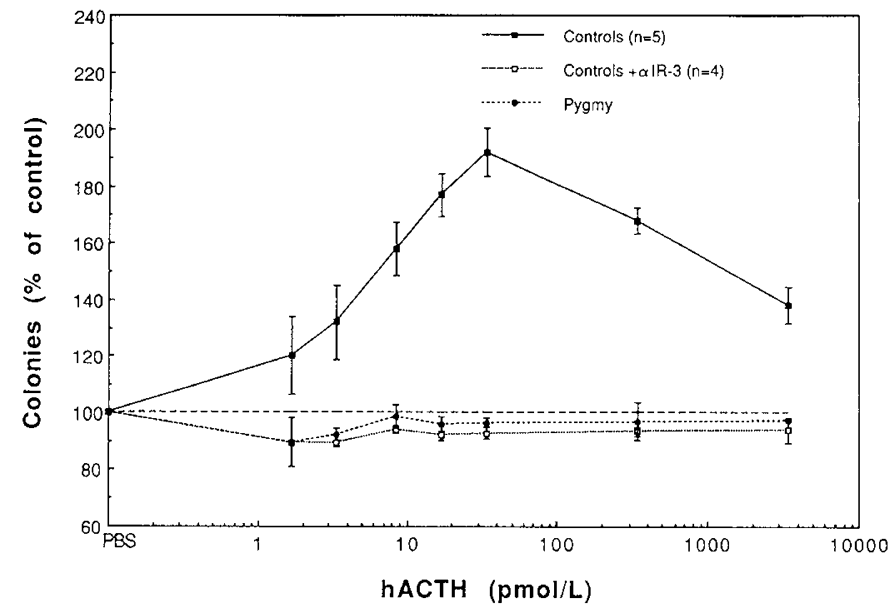

Figure 3. hACTH responsiveness. The mean peak clonal response of normal T-lymphoblast cell lines to hACTH was $192 \pm 8.6 \%$. After preincubation with $\alpha \mathrm{IR}-3$, responsiveness to hACTH was completely blunted. Additionally, the pygmy T-lymphoblast cell line showed no responsiveness to hACTH.

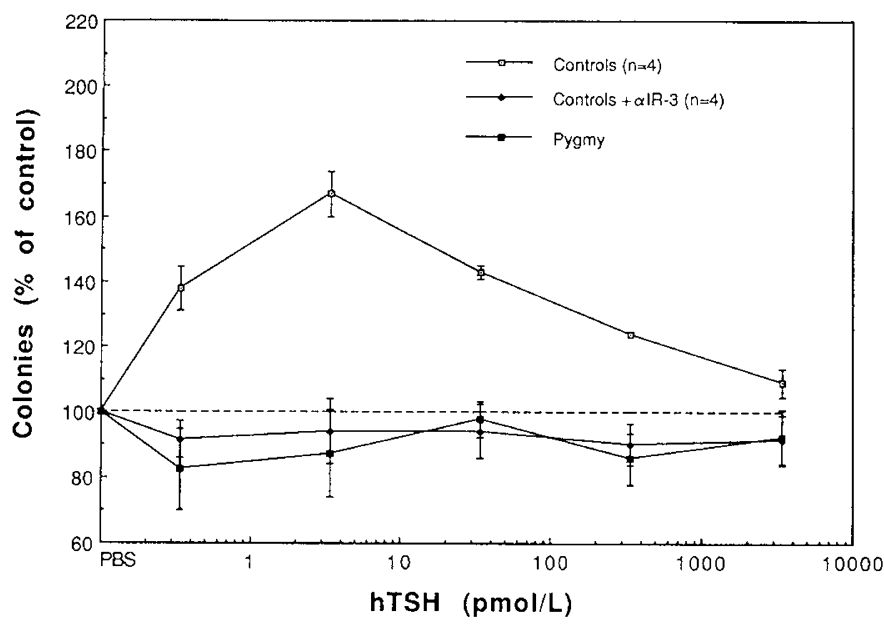

Figure 4. hTSH responsiveness. The mean peak clonal response of normal T-lymphoblast cell lines to hTSH was $167 \pm 7.0 \%$. After preincubation with $\alpha \mathrm{IR}-3$, responsiveness to hTSH was completely blunted. Additionally, the pygmy T-lymphoblast cell line showed no responsiveness to hTSH.

Pygmy T-lymphoblast cell line: hIGF-I, hPTH, hACTH, and hTSH responsiveness. Mean basal colony counts were $76.8 \pm$ 13.4 (hIGF-I), $39.7 \pm 11.0$ (hPTH), $46.1 \pm 10.8$ (hACTH), and $53.4 \pm 24.0$ (hTSH) ( $p=$ NS versus normal T-lymphoblast cell lines in each case).

The mean first peak clonal response of the pygmy $\mathrm{T}$ lymphoblast cell line after stimulation with hIGF-I was less than baseline, whereas the second mean peak response was 112 $\pm 8.2 \%$ occurring at an IGF-I concentration of $100 \mu \mathrm{g} / \mathrm{L}$ (mean of five experiments) ( $p=0.0004$ between entire pygmy and normal response curves) (Fig. 1).

After stimulation with $\mathrm{hPTH}$, the mean peak clonal response of the pygmy T-lymphoblast cell line $[122 \pm 1.5 \%$ (mean of seven studies)] was significantly reduced compared to that of normal T-lymphoblast cell lines $(p<0.0001$ between entire pygmy and normal response curves) (Fig. 2).

With hACTH stimulation, the mean peak clonal response of the pygmy T-lymphoblast cell line was reduced to less than 
baseline $[99 \pm 4.2 \%$ (mean of four studies) $](p<0.0001$ between entire pygmy and normal response curves) (Fig. 3).

The mean peak clonal response of the pygmy T-lymphoblast cell line after stimulation with hTSH was also reduced to less than baseline $[98 \pm 5.5 \%$ (mean of three studies) $](p=0.0001$ between entire pygmy and normal response curves) (Fig. 4).

\section{DISCUSSION}

In this study, we confirm that hIGF-I induces a bimodal (two-peak) clonal response by HTLV-II-transformed Tlymphoblast cell lines established from normal individuals (5). We also show that physiologic concentrations of hPTH, hACTH, and hTSH stimulate the clonal proliferation of normal T-lymphoblast cell lines and, as deduced from experiments using an MAb against the IGF-I receptor, that this growth stimulation, like that in response to hGH (12), seems to be mediated by local IGF-I. These clonal responses were not significantly altered by preincubation with a similar class of anti-neutrophil MAb, underscoring the specificity of the neartotal blockade of the clonal responses to hPTH, hACTH, and hTSH induced by the IGF-I-receptor MAb. Finally, a Tlymphoblast cell line established from an Efe pygmy is resistant to the growth-promoting action of these four hormones, on the basis of intrinsic resistance of the pygmy T-cell line to IGF-I.

Pretreatment of normal T-lymphoblast cell lines with $\alpha \mathrm{IR}-3$ antibody against the IGF-I receptor blocked clonal responsiveness to all concentrations of IGF-I. This finding was somewhat unexpected inasmuch as we had previously shown (9), using insulin as the ligand, in the presence and absence of $\alpha \mathrm{IR}-3$, that the clonal responses to physiologic insulin concentrations were mediated through the insulin receptor, whereas those to supraphysiologic concentrations of insulin were mediated through the IGF-I receptor because only the latter could be blocked by $\alpha \mathrm{IR}-3$ pretreatment. Thus, to explain our current findings of $\alpha$ IR-3-induced blockade of both physiologic and supraphysiologic hIGF-I responses, we conclude that the former are mediated through the IGF-I receptor, whereas the latter are mediated by hybrid IGF-I-insulin receptors (13), the responses of which are blocked by pretreatment with antibody to the IGF-I receptor. Using analagous reasoning, the pygmy $T$-cell line, which demonstrates no first peak but a small second peak clonal response to IGF-I, may possess a hybrid IGF-I-insulin receptor population capable of responding to IGF-I.

That IGF play a role in the in vitro action of PTH on bone is suggested by studies of neonatal mouse calvariae in which exposure to synthetic bovine PTH $(1-12 \mathrm{nmol} / \mathrm{L})$ resulted in a dose-dependent secretion of both IGF-I (5- to 10-fold) and IGF-II (1.5- to 2-fold) into conditioned medium (14). Using a cultured rat calvarial model, Canalis et al. (15) showed that synthetic rat PTH-(1-34) (1-100 nmol/L) stimulated thymidine incorporation into DNA up to 4.8-fold and increased secretion of IGF-I into the medium 2- to 4-fold; pretreatment of these cells with antibody to IGF-I prevented PTH-stimulated collagen synthesis but not mitogenesis. Synthetic rat PTH-(134) $(0.1-10 \mathrm{nmol} / \mathrm{L})$ stimulation of parietal bone cultured from 22-d-old rat fetuses resulted in stimulation of IGF-I transcripts by $100-200 \%$ after $6 \mathrm{~h}$ and in a $40-200 \%$ increase in IGF-I concentration in the medium at $24 \mathrm{~h}$ (16). Using an in vivo calf model with catheterized hepatic and portal vessels, Coxam et al. (17) demonstrated that a synthetic bovine PTH-(1-34) infusion stimulated hepatic production of IGF-I. Thus, there is ample evidence that PTH regulates IGF-I production and action in vitro and in vivo.

The role of IGF in adrenocortical tissue growth is incompletely understood. In the rat, adrenal IGF-I and IGF-II mRNA decreased during the regrowth period after unilateral adrenalectomy and after ACTH-(1-24) infusion despite a significant increase in gland size (18). In vitro, biosynthetic IGF-I (5.3 $\mathrm{nmol} / \mathrm{L})$ and $\mathrm{ACTH}-(1-24)(55.6 \mathrm{pmol} / \mathrm{L})$ each stimulate steroidogenesis in bovine adrenal fasciculata tissue, with the combination showing synergism. Cell multiplication, however, was unaffected by IGF-I (19). Voutilainen and Miller (20) showed that ACTH and dibutyryl-cAMP stimulation of cultured human fetal adrenal tissue resulted in increased levels of mRNA for both IGF-II and cholesterol side-chain-cleavage enzyme, without significantly affecting IGF-I mRNA (20). More recently, Pham-Huu-Trung et al. (21) showed that IGF-I $(38.2 \mu \mathrm{g} / \mathrm{L})$ stimulation of human adrenal tissue resulted in initial increases in production of dehydroepiandrosterone, androstenedione, 11-desoxycortisol, and glucocorticoids consistent with activation of $17 \alpha-, 21-$, and $11 \beta$-hydroxylase enzyme activities. Lastly, recombinant human IGF-I and IGF-II (1000 $\mu \mathrm{g} / \mathrm{L}$ ) both induced proliferation of human fetal adrenocortical cells by 1.8- to 2 -fold and 100- to 200-fold, respectively. In the same study, IGF-II mRNA was found in great abundance in fetal but not in adult adrenocortical cells, with IGF-I mRNA higher in adult than in fetal cells (22). These findings are consistent with a role for IGF in adrenocortical growth and function in certain species, with IGF-II more active in the fetal state and IGF-I more active postnatally. In addition, short-term GH administration (10 d) to children with isolated GH deficiency results in a significant increase in ACTH-stimulated levels of circulating IGF-I (23).

A role for IGF in thyroid growth is suggested by findings using the FRTL-5 rat thyroid cell line, the cellular proliferation of which is stimulated by IGF, TSH, and thyroid-stimulating immunoglobulins. The mitogenic effects of TSH $(1 \mathrm{nmol} / \mathrm{L})$ in this system are blocked by $\sim 50 \%$ after pretreatment with sm-1.2 MAb to IGF-I (24). Cultured human thyroid follicular cells secrete IGF-I and IGFBP into culture medium in a concentration-dependent fashion after stimulation with purified bovine TSH $\left(10^{-1}-10^{2} \mathrm{nmol} / \mathrm{L}\right)(25)$. Thus, IGF-I seems to subserve the growth-promoting actions of TSH on the thyroid.

We previously provided three lines of evidence suggesting that IGF-I resistance was present in the currently studied Efe pygmy and may account for his short stature. First, the pygmy Tlymphoblast cell line showed no clonal proliferation in response to direct stimulation with physiologic concentrations of either hGH, hIGF-I, or the hIGF-I analog [Q3,A4,Y15,L16]IGF-I (which binds to the type I IGF receptor but not to IGFBP). Second, this pygmy T-lymphoblast cell line, unlike normal HTLV-IItransformed T cells, demonstrated no specific hIGF-I binding (5). Because the growth-promoting effects of hGH in this system are mediated through a local IGF-I loop (12), these findings led us to 
conclude that IGF-I resistance was the primary variation in the pygmy, with GH resistance secondary. In separate experiments, we showed that hGH preincubation of normal T-lymphoblasts induced complete growth resistance to subsequent stimulation by human insulin at concentrations ranging from 1.2 to $43.2 \times 10^{3}$ $\mathrm{pmol} / \mathrm{L}(26)$, and that this effect of hGH also required local IGF-I (6). That neither hGH nor hIGF-I preincubation of the pygmy T-cell line, however, induced resistance to subsequent mitogenic stimulation by insulin (6) provided the third line of evidence for intrinsic IGF-I resistance in this pygmy and evidence that an intact IGF-I receptor mechanism is needed for GH-induced insulin resistance in this cell system. Our present results indicate that the mitogenic effects of PTH, ACTH, and TSH on HTLV-IItransformed T-lymphoblast cell lines are largely mediated by IGF-I or require IGF-I as a cofactor, and provide a fourth line of evidence that IGF-I resistance is the primary variation in this Efe pygmy.

\section{REFERENCES}

1. Van Wyk JJ, Conti M, del Monte P, Takahashi SI 1989 The role of somatomedins in the growth and function of endocrine tissues. In: Sizonenko PC, Aubert ML (eds) The Endocrinology of Adolescence. Raven Press, New York, pp 127-140

2. Perry HM, Chappel JC, Bellorin-Font E, Tamao J, Martin KJ, Teitelbaum SL 1984 Parathyroid hormone receptors in circulating human mononuclear cells. J Biol Chem 259:5531-5535

3. Smith EM, Brosnan P, Meyer WJ, Blalock JE 1987 An ACTH receptor on human mononuclear leukocytes. N Engl J Med 317:126-169

4. Endo T, Ohno M, Kotani S, Gunji K, Onaya T 1993 Thyrotropin receptor in non-thyroid tissues. Biochem Biophys Res Commun 190:774-779

5. Geffner ME, Bailey RC, Bersch N, Vera JC, Golde DW 1993 Insulin-like growth factor-I unresponsiveness in an Efe pygmy. Biochem Biophys Res Commun 193:1216-1223

6. Geffner ME, Bailey RC, Bersch N, Golde DW 1994 Growth hormone induces resistance to the mitogenic action of insulin through local YGF-I: studies in normal and pygmy T-cell lines. Diabetes 43:68-72

7. Chen ISY, Quan SG, Golde D 1983 Human T-cell leukemia virus type II transforms normal human lymphocytes. Proc Natl Acad Sci USA 80:7006-7009

8. Chen ISY, McLaughlin J, Gasson JC, Clark SC, Golde DW 1983 Molecular characterization of genome of a novel human T-cell leukemia virus. Nature 305:502-505

9. Geffner ME, Kaplan SA, Bersch N, Lippe BM, Smith WG, Nagel RA, Santuli Jr TV, Li CH, Golde DW 1987 Leprechaunism: in vitro insulin action despite genetic insulin resistance. Pediatr Res 22:286-291
10. Saxon A, Stevens RH, Golde DW 1978 T-lymphocyte variant of hairy-cell leukemia. Ann Intern Med 88:323-326

11. Van Wyk JJ, Graves DC, Casella SJ, Jacobs S 1985 Evidence from monoclonal antibody studies that insulin stimulates deoxyribonucleic acid synthesis through the type I somatomedin receptor. J Clin Endocrinol Metab 61:639-643

12. Geffner ME, Bersch N, Lippe BM, Rosenfeld RG, Hintz RL, Golde DW 1990 Growth hormone mediates the growth of T-lymphoblast cell lines via locally generated insulin-like growth factor I. J Clin Endocrinol Metab 71:464-469

13. Frattali AL, Treadway JL, Pessin JE 1992 Insulin/IGF-I hybrid receptors: implications for the dominant-negative phenotype in syndromes of insulin resistance. $\mathrm{J}$ Cell Biochem 48:43-50

14. Linkhart TA, Mohan S 1989 Parathyroid hormone stimulates release of insulin-like growth factor-I (IGF-I) and IGF-II from neonatal mouse calvaria in organ culture. Endocrinology 125:1484-1491

15. Canalis E, Centrella M, Burch W, McCarthy TL 1989 Insulin-like growth factor I mediates selective anabolic effects of parathyroid hormone in bone cultures. J Clin Invest 83:60-65

16. McCarthy TL, Centrella M, Canalis E 1989 Parathyroid hormone enhances the transcript and polypeptide levels of insulin-like growth factor I in osteoblast-enriched cultures from fetal rat bone. Endocrinology 124:1247-1253

17. Coxam V, Davicco M-J, Durand D, Bauchart D, Barlet J-P 1990 Parathyroid hormone and calcitonin may modulate hepatic IGF-I production in calves. Acta Endocrinol $123: 471-475$

18. Townsend SF, Dallman MF, Miller WL 1990 Rat insulin-like growth factor-I and -II mRNAs are unchanged during compensatory adrenal growth but decrease during ACTH-induced adrenal growth. J Biol Chem 265:22117-22122

19. Pham-Huu-Trung, Binoux M 1990 Insulin-like growth factor I (IGF I) induces cortisol production in bovine adrenocortical cells in primary culture. J Steroid Biochem 36:583-588

20. Voutilainen R, Miller WM 1987 Coordinate tropic hormone regulation of mRNAs for insulin-like growth factor II and the cholesterol side-chain-cleavage enzyme, P450ssc, in human steroidogenic tissues. Proc Natl Acad Sci USA 84:1590-1594

21. Pham-Huu-Trung MT, Villette JM, Bogyo A, Duclos JM, Fiet J, Binoux M 1991 Effects of insulin-like growth factor I (IGF-I) on enzymatic activity in human adrenocortical cells. Interactions with ACTH. J Steroid Biochem Molec Biol 39:903909

22. Mesiano S, Mellon SH, Jaffe RB 1993 Mitogenic action, regulation, and localization of insulin-like growth factors in the human fetal adrenal gland. J Clin Endocrinol Metab 76:968-976

23. Merola B, Rossi E, Longobardi S, Selleri A, Esposito V, Colao A, Cataldi M, Ferone D, Lombardi G 1993 Further evaluation of IGF-I responsiveness to ACTH in children affected with IGHD. Horm Mctab Res 38:150-153

24. Maciel R, Moses A, Villone G, Tramontano D, Ingbar S 1988 Demonstration of the production and physiological role of insulin-like growth factor II in rat thyroid follicular cells in culture. $J$ Clin Invest 82:1546-1553

25. Tode R, Serio M, Rotella CM, Galli G. Franceschelli F, Tanini A, Toccafondi R 1989 Insulin-like growth factor-I: autocrine secretion by human thyroid follicular cells in primary culture. J Clin Endocrinol Metab 69:639-647

26. Geffner ME, Bersch N, Golde DW 1993 Growth hormone induces insulin resistance in Laron dwarf cells via lactogenic receptors. J Clin Endocrinol Metab 76:1039-1047 